OPEN ACCESS

Edited by:

Wei-Fan Chen,

Penn State Wilkes-Barre

United States

Reviewed by:

Hu Jian,

Jiangxi University of Finance

and Economics, China

Marinella Coco,

Università degli Studi di Catania, Italy

*Correspondence:

Ting Wang

wangting@cupl.edu.cn

Specialty section

This article was submitted to

Educational Psychology,

a section of the journal

Frontiers in Psychology

Received: 31 January 2019

Accepted: 24 April 2019

Published: 09 May 2019

Citation:

Wang T (2019) Exploring the Mode of Entrepreneurship

Education Based on

the Legal-Business Compound

Competency in China.

Front. Psychol. 10:1055.

doi: 10.3389/fpsyg.2019.01055

\section{Exploring the Mode of Entrepreneurship Education Based on the Legal-Business Compound Competency in China}

Ting Wang*

School of Business, China University of Political Science and Law, Beijing, China

A perfect legal guarantee can ensure China's high-quality socio-economic development. At present, in terms of China's entrepreneurship education (EE), it is necessary to strengthen entrepreneurs' legal consciousness and respect for rules. The research establishes a model for legal-business compound competency (LBCC). It is a pioneering EE mode adapted to characteristics of China's market transition to cultivate interdisciplinary talents who excel at management and administration but also have a command of laws and regulations in EE. By utilizing behavioral event interview (BEl) and Delphi methods, factors affecting LBCC were summarized. Moreover, a questionnaire-based inquiry was conducted using graduates who received lawbusiness interdisciplinary entrepreneurship education (LBIEE) as subjects to collecting data to evaluate the cultivation effect of the EE mode. In the study, a model for LBCC was established from the three perspectives including knowledge, skill, and attitude. Additionally, cultivating competency of law-business interdisciplinary talents (LBITs) shows a significantly positive influence on compensation level and job satisfaction among graduates who have received the EE. The core task of LBIEE is to improve compound competency of students in legal-business to enable students to show entrepreneurial spirit with legal-business intelligence. It is considered an innovation in a mode of education adapted to the transition and development of China's market economy.

Keywords: entrepreneurship education, legal-business compound competency, law-business interdisciplinary talents, competency model, behavioral event interview

\section{INTRODUCTION}

Entrepreneurship education (EE) pursues the development of student competency to grasp commercial opportunity (Daniela et al., 2016) and adapt to complex business environments (Ho et al., 2014; Rauch and Hulsink, 2015). Whether and how competency is cultivated through EE is proposed by Gorman et al. (1997). It is suggested that competency can be favorably cultivated via EE (Kuratko, 2005) while related meta-analysis also shows that EE is, on the whole, effective (Martin et al., 2013; Bae et al., 2014); however, super-fine multidisciplinary settings in educational contexts leads students passively receiving separate disciplinary cultures ( $\mathrm{Gu}, 2011)$. As a result, 
it is hard for students to develop a comprehensive competency in solving realistic problems in society $(\mathrm{Gu}, 2011)$. In the new era, with rapidly changing technologies and an ever-changing market environment, entrepreneurs need to face significant uncertainty. Therefore, they have to retain multidisciplinary knowledge and skills and show strong adaptability. In contrast, the essence of interdisciplinary talents lies in combination of knowledge, skill, and quality and therefore interdisciplinary talents are essential in the new era (Su and $\mathrm{Ma}, 2011$ ). Cultivating interdisciplinary talents is an important direction for development research and practice in EE (Gary, 2005; Daniela et al., 2016; Virginia and Carlos, 2018).

The cultivation of interdisciplinary entrepreneurial talents will meet the demand of a society for comprehensive, applicationoriented, and innovative talents to promote the development of society, the economy, and scientific technology (Wang and An, 2015; Karen and Dawn, 2016). The mode of innovation of inter-disciplinary talent cultivation in $\mathrm{EE}$ is constantly acknowledged and strengthened. Many colleges start to integrate business education with other disciplines, expecting to cultivate inter-disciplinary entrepreneurial talents. In the United States, there is no doubt that JD (Juris Doctor) or MBA (Master of Business Administration) are the most characteristic and attractive co-training projects (Chen and Qiu, 1996). Law-business interdisciplinary entrepreneurship education (LBIEE) underwent its first 5-year test period at the University of Virginia: this proved that inter-disciplinary education in law and management was feasible (John, 1982). Afterward, Harvard Business School and Northwestern University (United States) also expanded similar EE projects to cultivate LBITs (Lynn and Justin, 2005). Through JD/MBA education project, Harvard University aims to train students to master rigorous and centralized classroom knowledge, acquire practical expertise in law and management, and deepen their understanding of legal and business principles in their future career (Wang, 2017). However, Northwestern University's JD/MBA project pays more attention to practice, thus providing students with many practical learning opportunities to help them deal with many legal and business cross-cutting incidents (Wang, 2017).

A series of research achievements show that the cultivation characteristics of EE are influenced by their environment (Walter and Dohse, 2012; De Clercq et al., 2013), institution (Sascha and Jörn, 2016), and national background (Shepherd, 2011; Panagiotis, 2012). With the further development of legalization processes in China's economy, entrepreneurs will inflict a destructive blow to a start-up if they make a decision violating laws and business ethics (Baron et al., 2015). China's economic development during the transition period requires a great number of interdisciplinary talents who not only have a command of management but also show legal awareness (Wang, 2017). Therefore, in China's EE, it is necessary to strengthen the learning of law-based knowledge and cultivation of rule consciousness (Chai and Sun, 2012; Qu, 2015). In particular, with the internationalization of Chinese Enterprises, mastering the legal operating norms of overseas markets have been one of necessary attributes of entrepreneurial talents (Sun, 2018).
In 2010, Business School of China University of Political Science and Law (CUPL) started to explore the innovation of the law-business EE mode based on the construction of a pilot site for cultivating LBITs in quality engineering by the Ministry of Education of the People's Republic of China (Sun et al., 2012). China's LBIEE has been a new field which is under development in many universities (Huang et al., 2012; Zhao, 2015). A market economy means an economy ruled by law, so law is naturally integrated with business, which is an innate demand of entrepreneurial management ( $\mathrm{Wu}, 2012)$. The inclusion of the legal and ethical components in business education programs can provide the tools and processes necessary for executive decision making (Ostapski et al., 1996). The LBIEE mode emphasizes the integration of law and business elements (Li, 2012) to remove boundaries between disciplines (Andrew et al., 1996). In particular, it effectively solves problems arising during the transition of China's market economy (Xie, 2017; Wang, 2018) and improves the law-business interdisciplinary application ability of students in commercial activities by applying interdisciplinary education methods (Wang, 2017). Students that have a better understanding of the legal issues involved with invention and entrepreneurship can have more successful careers and better contribute to society (Borns, 2002).

According to the psychologically educational theory, the competency is the integration of knowledge, skill and attitude (KSA) which affect performance and hence the success of the individual (McClelland, 1973; Baartman and Bruijn, 2011). This research explores a model for legal-business compound competency (LBCC) established from these three perspectives including knowledge, skill, and attitude through behavioral event interview (BEI) which is the general method in the research of competency exploration. Then, we evaluate the influence of the LBIEE on the graduates' compensation level and job satisfaction by the survey data from CUPL. The purpose of this research is to improve the LBIEE mode by exploring characteristics of LBCC.

\section{MATERIALS AND METHODS}

For exploring the model of LBCC, the method of BEI is firstly executed to extract the competency factors of LBCC. Then, through the Delphi method, the experts involved to the LBIEE project are invited to score the importance degree of these factors for making the extracted factors more complete and effective. According to the process of BEI and Delphi methods, some of the most important characteristics of competency of LBITs can be ranked in qualitative analysis. Moreover, the scales for competency were formed in the survey questionnaire to collect the data for establishing a LBCC model in three perspectives of knowledge, skill, and attitude by extraction method of principal component analysis and quantitatively evaluating the influence of LBIEE project on the graduates.

\section{Behavioral Event Interview}

The method of BEI is an open exploration technology based on behavior review (McClelland, 1973; Spencer and Spencer, 1993; Larson, 2001). It is implemented according to the following 
process: interviewees narrate two or three successful and failed typical cases in their working lives and explain the whole process (including situation, participants, actions, thinking, and result) of events in detail. In the interview process, it is necessary to conduct effective guidance, and record the process. Finally, professionals make a summary, analysis, and code their findings to reveal core qualities in the staff interviewed (Adrian et al., 2014).

Through expert recommendation, 54 people with outstanding managerial ability in legal-business were interviewed. By utilizing BEI, 190 legal-business management cases were extracted in which there were 94 successful and 96 failed cases, respectively. On this basis, competency factors were extracted and coded from the cases to form a competency dictionary relating to LBCC. Moreover, frequencies of various competency factors in cases were calculated (Table 1).

\section{Delphi Method}

The Delphi method, also called the expert inquiry investigation method, is, in essence, an anonymous feedback inquiry method. The method can predict investigated problems through comprehensive analysis, which is implemented based on the following process: according to a rule-based procedure, anonymous experts are consulted for opinions or judgment of some predicted problems; According to the results of several investigations, and by virtue of knowledge and experience of experts, arrangement, statistics, and calculations are undertaken, and conclusions reached (Jon et al., 2017).

In the study, 27 teachers involved in this LBIEE project were invited to take part in the expert inquiry. The result obtained through the BEI was sent to various experts by e-mail. In this way, the experts can score the degree of importance of various factors concerning LBCC in Table $\mathbf{1}$ and also compensate for the dictionary of competency factors. After being subjected to two rounds of feedback, and supplemented by use of the Delphi method, the variance, standard deviation, etc., of competency factors in the second round were lower than those first obtained, and the dot pitch of upper and lower quartiles also slightly reduced. It indicated that experts' feedback was more concentrated after two rounds of feedback and supplementation through the Delphi method: the mean of scores, deduced by experts for various factors of competency of LBITs in the dictionary, have high reliability (Petra, 2016; Stefan et al., 2017). Moreover, according to expert opinions obtained based on the Delphi method, three competency factors (including knowledge of business ethics, accountancy knowledge, and knowledge of corporate governance) are added into "knowledge in management." Moreover, a competency factor (comprehensive thinking ability) is supplemented for "basic skill." The "attitude" also contains team awareness and achievement motivation; therefore, the dictionary of factors of competency of LBITs is rendered more complete.

According to statistical data pertaining to scores by experts, the top 12 ranked competency factors in terms of scores are listed in Table 2, and mainly concentrate on attitude and skill factors. This implies that the skill factors in an iceberg competency model (McClelland, 1973) and attitude factors under
TABLE 1 | Dictionary of competency factors in legal-business and statistical results (frequencies).

\begin{tabular}{|c|c|c|}
\hline $\begin{array}{l}\text { Factor of } \\
\text { competency }\end{array}$ & $\begin{array}{l}\text { Sub- } \\
\text { dimension }\end{array}$ & Name and frequency \\
\hline \multirow[t]{2}{*}{ Knowledge } & $\begin{array}{l}\text { Knowledge in } \\
\text { management }\end{array}$ & $\begin{array}{l}\text { Knowledge concerning managerial } \\
\text { economics (11), strategic } \\
\text { management (36), leadership (7), } \\
\text { financial management (13), } \\
\text { marketing (3), contract } \\
\text { management (12), human resource } \\
\text { management (HRM) (45), } \\
\text { organizational behavior (6), quality } \\
\text { management (3), supply chain } \\
\text { management (3), international } \\
\text { operation (4) }\end{array}$ \\
\hline & $\begin{array}{l}\text { Knowledge in } \\
\text { law }\end{array}$ & $\begin{array}{l}\text { Knowledge concerning contract } \\
\text { law (100), labor law (34), intellectual } \\
\text { property law (12), trademark law } \\
\text { (5), competition law (4), overseas } \\
\text { legal risk of enterprises (4), } \\
\text { commercial law (24), securities law } \\
\text { (5), tax law (3), procedural law (2) }\end{array}$ \\
\hline \multirow[t]{2}{*}{ Skill } & Basic skill & $\begin{array}{l}\text { Negotiation ability (32), ability of } \\
\text { interpersonal skill (3), } \\
\text { communication ability (52), ability of } \\
\text { analysis and identification (29), } \\
\text { executive capacity (23), flexible } \\
\text { application ability (18), learning } \\
\text { ability (8), innovation capacity (6), } \\
\text { self-discipline ability (12), position } \\
\text { competency (14), stress resistance } \\
\text { (3), ability to understand policy (15) }\end{array}$ \\
\hline & $\begin{array}{l}\text { Managerial } \\
\text { skill }\end{array}$ & $\begin{array}{l}\text { Team-based organization ability } \\
\text { (11), strategic decision-making } \\
\text { ability (13), risk management } \\
\text { capacity (117), resource integration } \\
\text { capability (15), ability of crisis } \\
\text { management (37), cross-cultural } \\
\text { management ability (5) }\end{array}$ \\
\hline Attitude & & $\begin{array}{l}\text { Legal consciousness (135), rule } \\
\text { consciousness ( } 37) \text {, consciousness } \\
\text { of rights safeguarding (50), sense of } \\
\text { responsibility (17), overall viewpoint } \\
\text { (33), rationality and calmness (43), } \\
\text { carefulness (44), dialectical thinking } \\
\text { (9), aggressiveness (8), objectivity } \\
\text { and fairness (4), win-win } \\
\text { cooperation (11), caution (42), } \\
\text { honesty and trustworthiness (9), } \\
\text { tenacity and determination (1) }\end{array}$ \\
\hline
\end{tabular}

Notes: Figure in the parentheses refers to the frequency of the competency factor in cases based on BEl.

ice surface are of great importance to EE. The factor "honesty and trustworthiness" returned the highest score, which is the most important characteristic of competency of LBITs and the factor which most needs cultivating during LBIEE.

\section{Data Collection Based on Questionnaire Survey}

To reflect the quality of cultivation of LBITs through this EE project, some questionnaires were issued to graduates 
TABLE 2 | Factors of LBCC ranked in terms of scores by experts based on the Delphi method.

\begin{tabular}{|c|c|c|c|c|c|}
\hline Rank & $\begin{array}{l}\text { Name of } \\
\text { competency factors }\end{array}$ & Mean & $\begin{array}{l}\text { Standard } \\
\text { deviation }\end{array}$ & Variance & $\begin{array}{c}\text { Dimension } \\
\text { of competency }\end{array}$ \\
\hline 1 & Honesty and trustworthiness & 4.67 & 0.483 & 0.233 & Attitude \\
\hline 2 & Communication ability & 4.57 & 0.598 & 0.357 & Skill \\
\hline 3 & Learning ability & 4.57 & 0.507 & 0.257 & Skill \\
\hline 4 & Team-based organization capacity & 4.57 & 0.598 & 0.357 & Skill \\
\hline 5 & Strategic decision-making capacity & 4.57 & 0.598 & 0.357 & Skill \\
\hline 6 & Legal consciousness & 4.52 & 0.68 & 0.462 & Attitude \\
\hline 7 & Rule consciousness & 4.52 & 0.68 & 0.462 & Attitude \\
\hline 8 & Sense of responsibility & 4.52 & 0.68 & 0.462 & Attitude \\
\hline 9 & Overall viewpoint & 4.52 & 0.602 & 0.362 & Attitude \\
\hline 10 & Innovation capacity & 4.48 & 0.75 & 0.562 & Skill \\
\hline 11 & Knowledge of strategic management & 4.48 & 0.68 & 0.462 & Knowledge \\
\hline 12 & Knowledge of contract law & 4.43 & 0.87 & 0.757 & Knowledge \\
\hline
\end{tabular}

who received LBIEE. The contents of questionnaires involved basic information including the evaluation of research objects on LBIEE and working conditions after they received EE. Additionally, based on factors affecting LBCC formed by using BEI and the Delphi method, a 5-point Likert scale for competency including 24 knowledge factors, 19 skill factors, and 16 attitude factors was established and used to evaluate ability levels of research objects.

During questionnaire design, to avoid common method bias, the following methods were used: (1) interviewees anonymously fill in questionnaires; (2) interviewers promise confidentiality and require interviewees to answer questions as honestly as possible; (3) interviewers define and explain any ambiguous or specialized professional questions (Nederhof, 1985; Podsakoff et al., 2003).

The Business School of China University of Political Science and Law first proposed LBIEE in China and has attracted a diversified elite cadre of students for enterprise management. It can represent the cultivation of demand and characteristics of competency of a majority of LBITs to some extent. On the premise of it being both voluntary and anonymous, interviewers issued paper and electronic questionnaires to law-business interdisciplinary graduates in the university who received LBIEE. All of the 145 questionnaires were returned (an effective return rate of $100 \%)$. The numbers of male and female samples were 89 and 56, which accounted for 61.4 and $38.6 \%$ of the whole sample, respectively. It approximated to the overall male-female ratio of graduates in the university who participate in LBIEE. The research objects are mainly aged from 30 to 40 years old and they are engaged in diversified careers. Therefore, the structure of investigated samples was deemed reasonable.

\section{Test of Reliability and Validity of Questionnaires}

Statistical analysis was conducted on the collected data. The values of Cronbach's alpha of various factors of LBCC in a Likert scale are all larger than 0.9 and the total $\alpha$ value in the scale reaches 0.964 (Table 3 ). This indicated that the scale for competency applied in the study shows a
TABLE 3 | Test index for reliability of questionnaires.

\begin{tabular}{llccc}
\hline Variable & $\begin{array}{c}\text { Variable } \\
\text { factor }\end{array}$ & $\begin{array}{c}\text { Measured } \\
\text { item }\end{array}$ & $\begin{array}{c}\alpha \text { value of } \\
\text { various factors }\end{array}$ & $\begin{array}{c}\text { Total } \alpha \text { of } \\
\text { the scale }\end{array}$ \\
\hline \multirow{2}{*}{ LBCC } & Knowledge & 24 & 0.945 & 0.964 \\
& Skill & 19 & 0.934 & \\
& Attitude & 16 & 0.945 & \\
\hline
\end{tabular}

TABLE 4 | Indices for KMO and Bartlett's test of sphericity of questionnaires.

\begin{tabular}{lcccc}
\hline Variable & $\begin{array}{c}\text { Verified value } \\
\text { for sample } \\
\text { sufficiency } \\
\text { based on } \\
\text { KMO }\end{array}$ & $\begin{array}{c}\text { Approximate } \\
\text { chi-square } \\
\text { value verified } \\
\text { by using } \\
\text { Bartlett's test } \\
\text { of sphericity }\end{array}$ & $\begin{array}{c}\text { Degree } \\
\text { of } \\
\text { freedom }\end{array}$ & Sig. \\
\hline LBCC & 0.863 & 7282.257 & 1711 & $<0.0001$ \\
\hline
\end{tabular}

high reliability (James, 1993). Moreover, the Kaiser-MeyerOlkin (KMO) values of various variables are all larger than 0.8. According to the reference standard of KMO value, it can be seen that there is a strong correlation between variables. Therefore, $\mathrm{KMO}$ is favorably suitable for factor analysis. The corresponding probability $(p)$ of observed values of statistical values obtained based on Bartlett's test of sphericity is less than 0.0001, suggesting a significant difference, therefore, Bartlett's test of sphericity is also suited to factor analysis (Table 4). Based on the aforementioned data, it can be seen that the scale for competency exhibits favorable validity (James, 1993).

\section{RESULTS}

\section{Benefits From LBIEE Project}

Data obtained through this investigation revealed that graduates think that they mainly benefit from the following aspects: systematically learning managerial knowledge, enhancing the consciousness of legal risk prevention, enriching interpersonal 
TABLE 5 | Benefits from LBIEE project.

\begin{tabular}{lcc}
\hline Benefits from learning & $\begin{array}{c}\text { Number } \\
\text { of } \\
\text { samples }\end{array}$ & $\begin{array}{c}\text { Proportion } \\
\text { of total } \\
\text { sample }\end{array}$ \\
\hline Systematically learning managerial knowledge & 107 & $73.8 \%$ \\
Strengthening consciousness of legal risk prevention & 103 & $71.0 \%$ \\
Enriching interpersonal network & 93 & $64.1 \%$ \\
Expanding business opportunity & 88 & $60.7 \%$ \\
Broadening the horizon and renewing ideas & 58 & $40.0 \%$ \\
Improving practical ability & 29 & $20.0 \%$ \\
Others & 5 & $3.5 \%$ \\
\hline
\end{tabular}

networks, expanding commercial opportunities, etc., through participation in this LBIEE project. The proportions of benefits in these four aspects are 73.8, 71.0, 64.1, and 60.7\%, respectively (Table 5), showing that the EE project realizes the training objective of gaining improvements in legal-business contexts. With the progressive improvement of China's market economy and the increase of the degree of internationalization therein, entrepreneurs need to be good at management but also proficient in mastering its rules. That is, they are required to have business intelligence and also be able to grasp and apply rules (Sun, 2018). Facing such a context, strengthening learning in law courses in $\mathrm{EE}$ is conducive to contributing to the success of graduates in innovation and when starting a business (Wang, 2018). The LBIEE project proposed by China University of Political Science and Law strengthens the competitiveness of graduates in complex business environments and also provides high-quality LBITs for China's market economy in the transition period.

\section{Establishing a Model for LBCC}

Competency was first proposed in research by an American psychologist McClelland (1973): by establishing an iceberg competency model, he suggested that personal qualities influencing work performance can be divided into knowledge, skill, self-cognition, quality, and motivation. Competency is the potential characteristics of a person, which enable them to attain excellent performance in their posts (Boyatzis and Royatzis, 1982), and it is the technology, ability, and personal characteristics required by an efficient or competent manager (Page et al., 1994). Overall, competency is defined as the requirement of a specific work for a person in knowledge, skill, and attitude (Spencer and Spencer, 1993). The LBCC model will be established based on these three aspects.

\section{Establishment of the Model for LBCC Based on Knowledge Factors}

In terms of knowledge, according to the characteristics of LBIEE, 24 items from two major categories (knowledge in management and law) are extracted from the scale used for LBCC, as shown in Table 1. Through the SPSS software-based tests, the KMO value reflecting the overall validity of knowledge factors in the questionnaires was 0.888 . This indicated that various knowledge factors in the questionnaires show many common factors and
TABLE 6 | Result of factor analysis on knowledge factors.

\begin{tabular}{|c|c|c|c|c|}
\hline & \multicolumn{4}{|c|}{ Component } \\
\hline & 1 & 2 & 3 & 4 \\
\hline Labor law & 0.846 & 0.102 & 0.163 & -0.043 \\
\hline Contract law & 0.759 & 0.264 & 0.203 & 0.091 \\
\hline Human resource management & 0.686 & -0.087 & 0.509 & 0.021 \\
\hline Procedural law & 0.679 & 0.413 & -0.150 & 0.199 \\
\hline Contract management & 0.651 & 0.234 & 0.374 & 0.234 \\
\hline Intellectual property law & 0.643 & 0.276 & 0.047 & 0.424 \\
\hline Trademark law & 0.641 & 0.324 & 0.039 & 0.509 \\
\hline Competition law & 0.549 & 0.469 & 0.140 & 0.505 \\
\hline Corporate governance & 0.483 & 0.373 & 0.403 & 0.134 \\
\hline Business ethics & 0.462 & 0.097 & 0.288 & 0.419 \\
\hline Accountancy & 0.105 & 0.808 & 0.184 & 0.035 \\
\hline Securities law & 0.261 & 0.774 & 0.075 & 0.201 \\
\hline Financial management & -0.024 & 0.720 & 0.445 & 0.078 \\
\hline Tax law & 0.356 & 0.659 & 0.257 & 0.173 \\
\hline Business law & 0.486 & 0.599 & 0.134 & 0.264 \\
\hline Overseas legal risk & 0.343 & 0.562 & 0.165 & 0.442 \\
\hline Strategic management & 0.140 & 0.195 & 0.747 & 0.269 \\
\hline Leadership & 0.210 & 0.124 & 0.737 & 0.133 \\
\hline Marketing & 0.076 & 0.412 & 0.659 & 0.227 \\
\hline Managerial economics & 0.159 & 0.301 & 0.655 & 0.241 \\
\hline Organizational behavior & 0.581 & -0.039 & 0.590 & 0.147 \\
\hline Supply chain management & 0.030 & 0.154 & 0.245 & 0.787 \\
\hline Quality management & 0.214 & 0.063 & 0.244 & 0.701 \\
\hline International operation & 0.068 & 0.325 & 0.441 & 0.522 \\
\hline
\end{tabular}

Extraction method, principal component analysis.

therefore the validity obtained through factor analysis is feasible. Factor analysis was conducted by applying principal component analysis (PCA) and varimax rotation was used to perform orthogonal rotation on the factor load matrix: four factors were thus acquired. The interpretation rate of the factors on the total variance was $67.174 \%$ and the result of factor analysis is shown in Table 6.

According to the aforementioned factor analysis, four factors can be extracted from 24 knowledge factors. Among them, knowledge of labor law, contract law, HRM, procedural law, contract management, intellectual property law, trademark law, competition law, corporate governance, and business ethics show a high load in the first factor, which can be called knowledge of Enterprise Compliance Governance; knowledge of accountant, securities law, financial management, tax law, business law, and overseas legal risk of enterprises exhibit a high load in the second factor, which can be named knowledge of Enterprise Asset Management; knowledge of strategic management, leadership, marketing, managerial economics, and organizational behavior have a high load in the third factor, which is called knowledge of Enterprise Management Strategy; knowledge of supply chain management, quality management, and international operation show a high load on the fourth factor, which is called knowledge of Enterprise Production and Operation. Therefore, the structure of the model for LBCC based on knowledge factors can be described by Figure 1. 


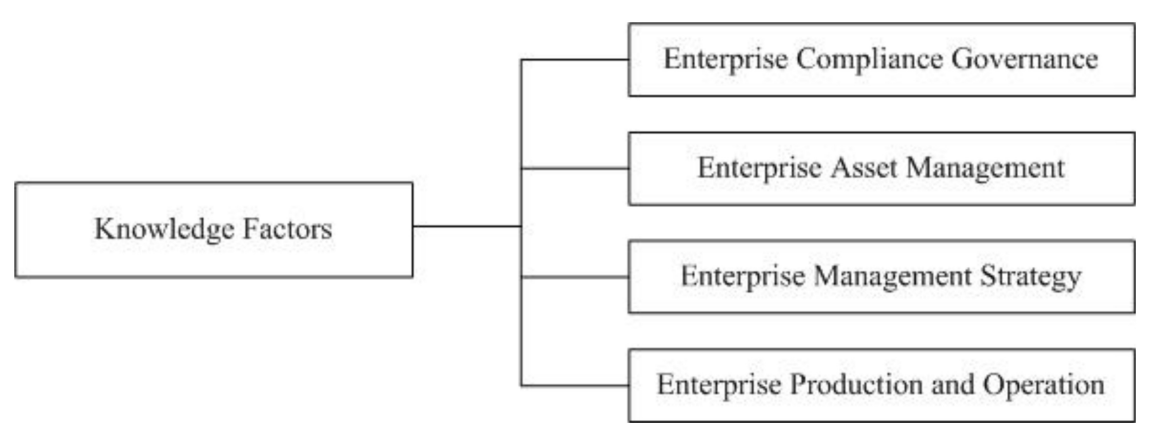

FIGURE 1 | LBCC model based on knowledge factors.

\section{Establishment of the Model for LBCC Based on Skill Factors}

In terms of skill, 19 items in two major categories (basic and managerial skills) were extracted from the scale of LBCC, as shown in Table 1. The KMO value reflecting the overall validity of skill factors in the questionnaires was 0.907 , which implied that items related to various skill factors in the questionnaires contain many common factors. As a result, the validity through factor analysis is feasible. PCA was applied to conduct factor analysis and varimax rotation was used to implement orthogonal rotation on factor load matrix to thus obtain three factors. The interpretation rate of the factors for the total variance reached $63.274 \%$ and the result obtained through factor analysis is displayed in Table 7.

According to the aforementioned factor analysis, three factors can be extracted from 19 skill factors. Therein, position competency, self-discipline ability, executive capacity, learning ability, team-based organization ability, stress resistance, ability to understand policy, comprehensive thinking ability, and flexible application ability show a high load on the first factor, which are called Work and Occupation Competency; resource integration capacity, cross-cultural management ability, ability of crisis management, risk management capacity, strategic decisionmaking ability, and innovation capacity exhibit a high load on the second factor, which are called Management and Control Capacity; communication ability, ability of interpersonal skill, negotiation ability, and ability of analysis and identification have a high load on the third factor, which are called Communication and Negotiation Ability. Therefore, the structure of the model for LBCC based on skill factors can be displayed in Figure 2.

\section{Establishment of the Model for LBCC Based on Attitude Factors}

In terms of attitudes, 16 items were extracted from the scale for LBCC, as shown in Table 1. The KMO value reflecting the overall validity of attitude factors in the questionnaires was 0.917 . This indicated that various attitude factors in the questionnaires have many common factors and therefore the validity through factor analysis is feasible. Factor analysis was carried out using PCA and the factor load matrix was subjected to orthogonal
TABLE 7 | Result of factor analysis on skill factors.

\begin{tabular}{|c|c|c|c|}
\hline & \multicolumn{3}{|c|}{ Component } \\
\hline & 1 & 2 & 3 \\
\hline Position competency & 0.751 & 0.073 & 0.153 \\
\hline Self-discipline ability & 0.744 & 0.124 & 0.009 \\
\hline Executive capacity & 0.724 & 0.168 & 0.334 \\
\hline Learning ability & 0.640 & 0.295 & 0.325 \\
\hline Team-based organization ability & 0.638 & 0.356 & 0.173 \\
\hline Stress resistance & 0.598 & 0.319 & 0.274 \\
\hline Ability to understand policy & 0.597 & 0.503 & 0.108 \\
\hline Comprehensive thinking ability & 0.567 & 0.452 & 0.301 \\
\hline Flexible application ability & 0.488 & 0.362 & 0.478 \\
\hline Resource integration capacity & 0.157 & 0.780 & 0.183 \\
\hline Cross-cultural management ability & 0.131 & 0.758 & 0.116 \\
\hline Ability of crisis management & 0.200 & 0.755 & 0.246 \\
\hline Risk management capacity & 0.342 & 0.731 & 0.081 \\
\hline Strategic decision-making ability & 0.258 & 0.657 & 0.363 \\
\hline Innovation capacity & 0.217 & 0.598 & 0.232 \\
\hline Communication ability & 0.291 & 0.176 & 0.840 \\
\hline Ability of interpersonal skill & 0.249 & 0.151 & 0.820 \\
\hline Negotiation ability & -0.016 & 0.359 & 0.777 \\
\hline Ability of analysis and identification & 0.456 & 0.200 & 0.643 \\
\hline
\end{tabular}

Extraction method, principal component analysis.

rotation by using varimax rotation to thus attain two factors. The interpretation rate of the factors for the total variance was $63.642 \%$ and the result obtained based on factor analysis is shown in Table 8.

According to the aforementioned factor analysis, two factors can be extracted from 16 attitude factors. Among them, team awareness, win-win cooperation, tenacity and determination, objectivity and fairness, achievement motive, aggressiveness, honesty and trustworthiness, dialectical thinking, rationality, calmness, and caution show a high load on the first factor, which can be called Personality Characteristics; legal consciousness, rule consciousness, sense of responsibility, carefulness, consciousness of rights safeguarding, and overall viewpoint exhibit a high load on the second factor, which can be called Risk Consciousness. Thus, the structure of the model for LBCC based on attitude factors can be described in Figure 3. 


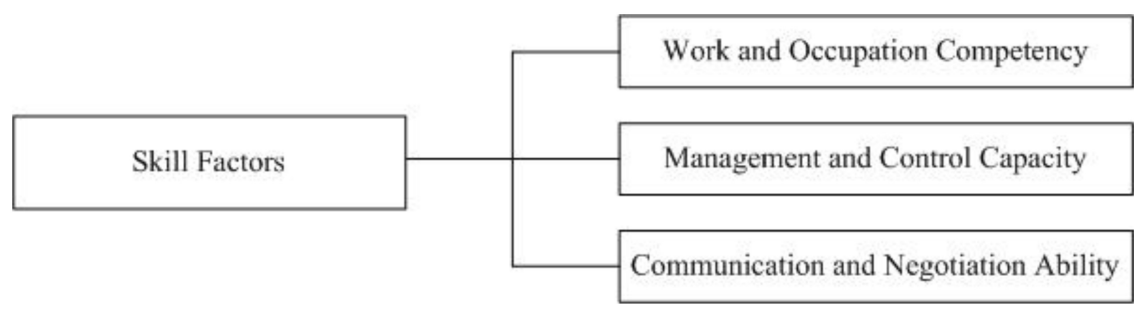

FIGURE 2 | LBCC model based on skill factors.

TABLE 8 | Result of factor analysis on attitude factors.

\begin{tabular}{lcc}
\hline & \multicolumn{2}{c}{ Component } \\
\cline { 2 - 3 } & $\mathbf{1}$ & $\mathbf{2}$ \\
\hline Team awareness & 0.789 & 0.260 \\
Win-win cooperation & 0.773 & 0.264 \\
Tenacity and determination & 0.772 & 0.355 \\
Objectivity and fairness & 0.735 & 0.365 \\
Achievement motive & 0.725 & 0.074 \\
Aggressiveness & 0.713 & 0.400 \\
Honesty and trustworthiness & 0.708 & 0.398 \\
Dialectical thinking & 0.590 & 0.459 \\
Rationality and calmness & 0.569 & 0.529 \\
Caution & 0.497 & 0.473 \\
Legal consciousness & 0.208 & 0.867 \\
Rule consciousness & 0.245 & 0.827 \\
Sense of responsibility & 0.458 & 0.696 \\
Carefulness & 0.480 & 0.637 \\
Consciousness of rights safeguarding & 0.152 & 0.606 \\
Overall viewpoint & 0.568 & 0.599 \\
\hline
\end{tabular}

Extraction method, principal component analysis.

\section{The Influence of Various Factors on LBCC}

Through factor analysis, it can be seen that LBCC can be well explained by using nine factors, involving knowledge of standard of enterprise operation, knowledge of enterprise asset management, knowledge of enterprise management strategy, knowledge of enterprise production and management, work competency, management and control capacity, communication and negotiation ability, personality characteristics, and risk consciousness. The nine factors are used to conduct multiple regressions on $\mathrm{LBCC}$ to analyze the influence of various factors on the LBCC. Assuming that $Y$ refers to LBCC and the aforementioned nine factors are separately represented by applying FAC1 to FAC9. The model is as follows:

$$
\begin{aligned}
\mathrm{Y}_{\mathrm{i}} & =\mathrm{b} 0+\mathrm{b} 1 \mathrm{FAC} 1+\mathrm{b} 2 \mathrm{FAC} 2+\mathrm{b} 3 \mathrm{FAC} 3+\mathrm{b} 4 \mathrm{FAC} 4 \\
& +\mathrm{b} 5 \mathrm{FAC} 5+\mathrm{b} 6 \mathrm{FAC} 6+\mathrm{b} 7 \mathrm{FAC} 7+\mathrm{b} 8 \mathrm{FAC} 8+ \\
& \text { b9FAC9 }+\xi \mathrm{i}
\end{aligned}
$$

By using SPSS, multiple regressions are carried out on the model and the result of data analysis is shown in Table 9. It can be seen from the regression coefficient of the model that, when regression equation contains the above nine variables, the significance probability of the equation is lower than 0.001 , rejecting the null hypothesis that the population regression coefficients are all equal to zero, therefore, the model should contain the nine variables. It can be seen from the analysis of regression coefficients that the significance level of regression coefficients is lower than 0.05 , which is verified by $t$-test. That is, the standardized multiple regression model is as follows:

$$
\begin{aligned}
\mathrm{Y} & =3.635+0.302 \mathrm{FAC} 1+0.266 \mathrm{FAC} 2+0.246 \mathrm{FAC} 3 \\
& +0.213 \mathrm{FAC} 4+0.227 \mathrm{FAC} 5+0.228 \mathrm{FAC} 6+0.18 \mathrm{FAC} 7 \\
& +0.233 \mathrm{FAC} 8+0.21 \mathrm{FAC} 9
\end{aligned}
$$

All factors are positively proportional to LBCC, implying that the improvement of abilities in the nine aspects can increase the LBCC to differing extents.

\section{The Influence of LBIEE on Graduates}

The purpose of EE is to improve students' comprehensive ability to adapt to complex environments in business activities (Rauch and Hulsink, 2015; Daniela et al., 2016). It is feasible to measure the training effect of $\mathrm{EE}$ based on two dimensions: objective compensation level and subjective job satisfaction of graduates in business activities.

Business education can bring long-term economic value for students, which significantly increases graduates' compensation

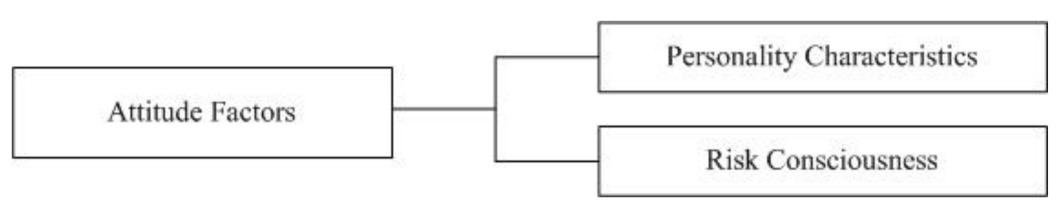

FIGURE 3 | LBCC model based on attitude factors. 


\begin{tabular}{|c|c|c|c|c|c|c|}
\hline & & \multicolumn{2}{|c|}{$\begin{array}{c}\text { Non-standardized } \\
\text { coefficient }\end{array}$} & \multirow{2}{*}{$\begin{array}{c}\begin{array}{c}\text { Standardized } \\
\text { coefficient }\end{array} \\
\text { Beta }\end{array}$} & \multirow[t]{2}{*}{$\mathbf{t}$} & \multirow[t]{2}{*}{ Sig. } \\
\hline & & B & $\begin{array}{l}\text { Standard } \\
\text { error }\end{array}$ & & & \\
\hline & (Constant) & 3.635 & 0.001 & & 4576.263 & 0.000 \\
\hline \multirow[t]{4}{*}{ Knowledge factors } & FAC1: knowledge of standard of enterprise operation & 0.124 & 0.001 & 0.302 & 134.878 & 0.000 \\
\hline & FAC2: knowledge of enterprise asset management & 0.110 & 0.001 & 0.266 & 129.291 & 0.000 \\
\hline & FAC3: knowledge of enterprise management strategy & 0.101 & 0.001 & 0.246 & 102.931 & 0.000 \\
\hline & FAC4: knowledge of enterprise production and management & 0.087 & 0.001 & 0.213 & 102.602 & 0.000 \\
\hline \multirow[t]{3}{*}{ Skill factors } & FAC5: work competency & 0.094 & 0.001 & 0.227 & 76.027 & 0.000 \\
\hline & FAC6: management and control capacity & 0.094 & 0.001 & 0.228 & 91.029 & 0.000 \\
\hline & FAC7: communication and negotiation ability & 0.074 & 0.001 & 0.180 & 77.859 & 0.000 \\
\hline \multirow[t]{2}{*}{ Attitude factors } & FAC8: personality characteristics & 0.096 & 0.001 & 0.233 & 83.166 & 0.000 \\
\hline & FAC9: risk consciousness & 0.086 & 0.001 & 0.210 & 80.285 & 0.000 \\
\hline
\end{tabular}

TABLE 10 | Data on the influence of LBIEE on compensation level of graduates.

\begin{tabular}{|c|c|c|c|c|c|c|}
\hline & \multirow[t]{2}{*}{ Model } & \multicolumn{2}{|c|}{$\begin{array}{c}\text { Non-standardized } \\
\text { coefficient }\end{array}$} & \multirow{2}{*}{$\begin{array}{c}\begin{array}{c}\text { Standardized } \\
\text { coefficient }\end{array} \\
\text { Beta }\end{array}$} & \multirow[t]{2}{*}{$t$} & \multirow[t]{2}{*}{ Sig. } \\
\hline & & $B$ & Standard error & & & \\
\hline \multirow[t]{2}{*}{1} & (Constant) & 0.457 & 0.818 & & 0.559 & 0.577 \\
\hline & LBCC & 0.713 & 0.224 & 0.258 & 3.188 & 0.002 \\
\hline
\end{tabular}

TABLE 11 | The influence of LBIEE on graduate job satisfaction.

\begin{tabular}{|c|c|c|c|c|c|c|}
\hline & & \multicolumn{2}{|c|}{$\begin{array}{c}\text { Non-standardized } \\
\text { coefficient }\end{array}$} & \multirow{2}{*}{$\begin{array}{c}\begin{array}{c}\text { Standardized } \\
\text { coefficient }\end{array} \\
\text { Beta }\end{array}$} & \multirow[t]{2}{*}{$t$} & \multirow[t]{2}{*}{ Sig. } \\
\hline & & $B$ & Standard error & & & \\
\hline \multirow[t]{2}{*}{1} & (Constant) & 48.727 & 9.134 & & 5.335 & 0.000 \\
\hline & LBCC & 6.759 & 2.497 & 0.221 & 2.707 & 0.008 \\
\hline
\end{tabular}

level (Jonathan et al., 2010). To observe the influence of LBIEE on the compensation level of graduates, the competency level of graduates in legal-business after receiving LBIEE was taken as the independent variable. Moreover, the annual salary of graduates was considered as a dependent variable. Through regression analysis, it can be seen, from Table 10, that the competency level in legal-business shows a significantly positive correlation with graduate salary. This indicates that LBIEE can improve the compensation level of graduates and the LBCC strengthens the comprehensive quality of graduates in career development. Graduates make a high-quality human capital investment in LBIEE.

The level of job satisfaction of graduates is an overall view after comprehensively considering various factors and it is a key factor for measuring education quality (Yue, 2013). Education can indirectly influence job satisfaction of graduates through various factors including salary and physical conditions (Eugenia and Luis, 2007). Entrepreneurial activity not only can bring material welfare but enhance job satisfaction and well-being (Wim et al., 2014). To explore the influence of LBIEE on job satisfaction of graduates, the competency of graduates in legal-business contexts after receiving LBIEE was regarded as the independent variable. Moreover, the job satisfaction of graduates in business activities was considered as a dependent variable. Through regression analysis (Table 11), it can be seen that the competency level in legal-business contexts is positively proportional to graduate job satisfaction. This implied that LBIEE can improve graduate job satisfaction. The LBCC is not only conducive to improving the ability of graduates in commercial management context but can also strengthen their adaptability to complex external business competition during the transition of China's economy. Establishing the concept of rule of law and rule consciousness is conducive to commercial development.

\section{CONCLUSION AND DISCUSSION}

The China University of Political Science and Law proposed the cultivation of LBITs characterized by possessing business and law intelligence, quick thinking, and strong actions. The university first launched the LBIEE project in 2010 and started an upsurge in innovative LBIEE modal development. LBIEE complies with the 
direction of innovating talent cultivation through EE in China's universities and also satisfies the practical needs of standardized, legalized development of the market economy for cultivating interdisciplinary talents (Chai and Sun, 2012). The core task of LBIEE is to improve students' LBCC and enable students to show entrepreneurial spirit with legal-business intelligence (Sun, 2012). For LBIEE, it needs to pay attention to cultivate legal-business intelligence in the following ways:

\section{Integrating Legal Thinking Into Business Logics}

As an independent discipline, business EE has its complete course system, including core curriculum and specialized curriculum. The purpose of the design logic of courses is to cultivate leaders in commercial circles who exhibit relatively comprehensive knowledge systems in management and also show entrepreneurial spirit. Such an education program is likely to lead to homogenization (Stewart and Anne, 2003; Datar et al., 2013). LBIEE incorporates legal thinking into the system of business. In terms of curriculum provision, law courses related to business need to be set, for example, contract law, economic law, tax law, and WTO legal regulation (Wang, 2018). This can equip graduates with entrepreneurship-related laws and regulations and a knowledge bank of policy rules and a grasp of various skills (planning, marketing, decisionmaking, and risk assessment) required in entrepreneurship. The LBCC can effectively improve students' entrepreneurial ability and urge them to take delight, and dare to participate, in entrepreneurship (Lu, 2015).

\section{Building Legal Awareness in Commercial Spirit}

Traditional EE tends to emphasize innovation, breakthrough, and entrepreneurial spirit that dare to face failure. Many people think that it contradicts legal consciousness, and especially in the initial development period of China's market economy, many excellent entrepreneurs have failed due to a lack of legal consciousness $(\mathrm{Qu}, 2015)$. LBIEE pays much attention to building correct values in business for students. By holding a series of courses, lectures, and case discussions related to legal-business, students' commercial spirit is endowed with more connotative meaning. In this way, legal consciousness and business ethics imperceptibly influence students' decision-making behaviors. The case-based course of most characteristic influence is lawbusiness management, which realizes the integration of law and business knowledge in teaching research of management cases ( $\mathrm{Mu}, 2012)$. On this basis, it is expected to train students to have an awareness of accepting laws and rules as a necessary constraint when facing practical problems in business.

\section{Legal Risk Prevention in Business Competition}

Significant business competition implies significant risk: at present, during the transition of China's economy, legal regulations have not yet been fully embedded and there are many uncertainties in market environment. Therefore, many enterprises frequently consider business risk during competition while ignoring legal risk. As a result, legal risk has been an important factor leading to entrepreneurship failure (Xie, 2017), which brings many unnecessary hidden dangers in business management for enterprise development (Baron et al., 2015). Additionally, Chinese enterprises are frequently subject to foreign law while implementing the "Going global" internationalization strategy. Transnational management cases evincing significant loss caused by China's enterprises failing to evaluate legal risk have become common in recent years (Wang, 2012). LBIEE neither means cultivating entrepreneurs into professional legal talents nor requires students to learn legal provisions by rote in this training program: it lets students know of the legal issues and pitfalls in business management through law-business interdisciplinary course teaching and case discussion. Furthermore, entrepreneurs can achieve success in business by taking effective strategies to prevent legal risk.

\section{Strengthening the Application of Legal Personnel in Commercial Activities}

Various management activities of an enterprise are always related to legal affairs. A majority of students who received law-business $\mathrm{EE}$ are professional managers in various domains at different positions. Besides, a batch of advanced professional layers in major law firms in China also participates in LBIEE and they bring their rich experience in legal affairs from their client portfolios. LBIEE leads to an interpersonal network satisfaction for sharing legal-business experience (Sun, 2012). Through interaction between students, practical problems of students in enterprises are discussed as law-business cases ( $\mathrm{Ge}$ and $\mathrm{Mu}$, 2010), which provide systematic solutions to business activities by using law-business conjoined thinking while also reflecting the importance of participating in LBIEE.

\section{Limitations and Suggestions}

This research is an exploratory factor analysis for establishing the model of LBCC by the process and methods of competency research. However, due to the limited purpose of this study, the training effect of the LBIEE project is only examined by the influence on objective compensation level and subjective job satisfaction of the graduates. Empirical studies relating to the effects of LBIEE projects on other aspects of graduates (e.g., entrepreneurial intention) need to be added and strengthened in the future researches for better improving this pioneering $\mathrm{EE}$ mode. In addition, the survey of this research only focus on Business School of China University of Political Science and Law (CUPL) started to explore the innovation of the LBIEE mode, which limits the generalizability of the results. Future researches ought to expand the samples to study individuals in different LBIEE projects. Moreover, this research is primarily based on the Chinese context because the LBIEE mode adapted to characteristics of China's market transition which requires a great number of LBITs who not only have a command of management but also show legal awareness. Whether the LBIEE mode is suitable for the development environment of foreign 
countries has not been discussed. The wider applicability of this LBIEE mode can be further explored in future researches.

\section{AUTHOR CONTRIBUTIONS}

TW provided substantial contributions to the research design and data analysis. TW wrote and revised the manuscript. TW approved of this version of the manuscript to be published.

\section{REFERENCES}

Adrian, B., Paloma, C., and Charlotte, C. (2014). Storytelling in the selection interview? How applicants respond to past behavior. J. Bus. Psychol. 29, 593-604.

Andrew, S. O., John, O., and Gaston, T. G. (1996). The legal and ethical components of executive decision-making: a course for business managers. J. Bus. Ethics. 15, 571-579. doi: 10.1007/BF00381932

Baartman, L. K. J., and Bruijn, E. D. (2011). Integrating knowledge, skills and attitudes: conceptualising learning processes towards vocational competence. Edu. Res. Rev. 6, 125-134. doi: 10.1016/j.edurev.2011.03.001

Bae, T. J., Qian, S., Miao, C., and Fiet, J. O. (2014). The relationship between entrepreneurship education and entrepreneurial intentions: a meta-analytic review. Enterp. Theory Pract. 38, 217-254. doi: 10.1111/etap.12095

Baron, R. A., Zhao, H., and Miao, Q. (2015). Personal motives, moral disengagement, and unethical decisions by entrepreneurs: cognitive mechanisms on the slippery slope. J. Bus. Ethics 128, 107-118.

Borns, R. J. (2002). "The legal aspects of engineering education, entrepreneurship, and invention," in Proceedings of the 32nd Annual Frontiers in Education, (Piscataway, NJ: IEEE).

Boyatzis, R. E., and Royatzis, R. (1982). The Competent Manager: A Model for Effective Performance. New York, NY: Wiley.

Chai, X. Q., and Sun, X. Z. (2012). On Setting Up the Management School of Law and Business, Legal-business Management Review. China: Economy \& Management Publishing House, 19-26.

Chen, B. F., and Qiu, Q. (1996). The reform of harvard management education and its enlightenment. Nankai J. 3, 57-60.

Daniela, M., Rainer, H., Norbert, K., and Birgit, W. (2016). The impact of entrepreneurship education on the entrepreneurial intention of students in science and engineering versus business studies university programs. Technol. Forecast. Soc. 104, 172-179. doi: 10.1016/j.techfore.2015.11.006

Datar, M. S., Garvin, A. D., and Cullen, G. P. (2013). Rethinking the MBA Business Education at a Crossroads. Brighton, MA: Harvard Business Press, 17-42.

De Clercq, D., Lim, D. S. K., and Oh, C. H. (2013). Individual-level resources and new business activity: the contingent role of institutional context. Entrepreneurship: Theor. Pract. 37, 303-330. doi: 10.1111/j.1540-6520.2011. 00470.x

Eugenia, F. F., and Luis, E. V. L. (2007). Evaluation of the effects of education on job satisfaction: independent single-equation vs. structural equation models. J. Int. Adv. Econ. Res. 13, 157-170. doi: 10.1007/s11294-007-9081-3

Gary, B. (2005). The entrepreneurship curriculum for music students: thoughts towards a consensus. Coll. Music Sym. 45, 13-24.

Ge, J. H., and Mu, F. L. (2010). Exploration of "law - business" in case teaching practice. J. Chin. Univ. Edu. 7, 67-70.

Gorman, G., Hanlon, D., and King, W. (1997). Some research perspectives on entrepreneurship education, enterprise education, and education for small business management: a ten-year literature review. Int. Small Bus. J. 15, 56-77. doi: $10.1177 / 0266242697153004$

Gu, H. L. (2011). "Snow's proposition" and interdisciplinary research in the humanities and social sciences. Soc. Sci. Chin. 32, 14-22. doi: 10.1080/02529203. 2011.598290

Ho, Y.-P., Low, P.-C., and Wong, P.-K. (2014). Do university entrepreneurship programs influence students' entrepreneurial behavior? An empirical analysis of university students in Singapore. Adv. Stud. Entrepreneurship Innov. Econ. Growth 24, 65-87.

\section{FUNDING}

This research was supported by grants from the Beijing Social Science Fund Project and the project numbers are 17YJB008, the National Natural Science Foundation of China and the project numbers are 71874205, the Scientific Research Project in CUPL and the project numbers are 16ZFG79002, and the Excellent Young and Middle-aged Teacher Development Support Program in CUPL and the project numbers are 01146511.

Huang, Z. X., Huang, L. J., and Song, Z. H. (2012). Entrepreneurial law education of college students: the necessity and recommendations. Chin. High. Educ. Res. 12, 76-78. doi: 10.16298/j.cnki.1004-3667.2012.11.018

James, O. B. (1993). Statistical Decision Theory and Bayesian Analysis (Springer Series in Statistics). Berlin: Springer.

John, W. K. (1982). An analysis of legal education and business education within the context of a J.D./MBA program. J. Legal Educ. 31, 512-530.

Jon, S., Richard, T. C., Stale, N., Ariel, O., and Jeffrey, R. (2017). Vincent, using the Delphi method to value protection of the Amazon rainforest. J. Ecol. Econom. 131, 475-484. doi: 10.1016/j.ecolecon.2016.09.028

Jonathan, P. O., Paul, L. D., Crook, T. R., and Craig, E. A. (2010). Does business school research add economic value for students? Acad. Manage. Learn. Educ. 9, 638-651. doi: 10.1007/s00268-017-4370-3

Karen, L. R., and Dawn, S. (2016). Entrepreneurial literacy and the second language curriculum. J. Hispania 99, 423-435.

Kuratko, D. F. (2005). The emergence of entrepreneurship education: development, trends, and challenges. Enterp. Theory Pract. 29, 577-597. doi: 10.1111/j.1540-6520.2005.00099.x

Larson, W. W. (2001). Ten-Minute Guide to Conducting a Job Interview. Indianapolis, IN: Macmill.

Li, J. H. (2012). Law and Business Administration and Its Basic Methods in LegalBusiness Management Review. China: Economy \& Management Publishing House, 40-51.

$\mathrm{Lu}$, Q. P. (2015). On the correlation between college entrepreneurship education and college students' entrepreneurial ability. J. Educ. Rev. 6, 21-24.

Lynn, W., and Justin, O. (2005). Crossing the charles: the experiences, networks, and career paths of Harvard JD/MBA Alumni. SSRN Electron. J. 8, 1-64. doi: $10.2139 /$ ssrn. 812425

Martin, B. C., McNally, J. J., and Kay, M. J. (2013). Examining the formation of human capital in entrepreneurship: a meta-analysis of entrepreneurship education outcomes. J. Bus. Ventur. 28, 211-224. doi: 10.1016/j.jbusvent.2012. 03.002

McClelland, D. C. (1973). Testing for competence rather than for "intelligence". Am. Psychol. 28:1.

Mu, F. L. (2012). Exploration and Study on Legal-Business Management Cases, in Legal-Business Management Review. China: Economy \& Management Publishing House, 194-202.

Nederhof, A. J. (1985). Methods of coping with social desirability bias: a review. Eur. J. Soc. Psychol. 15, 263-280. doi: 10.1002/ejsp.2420150303

Ostapski, S. A., Oliver, J., and Gonzalez, G. T. (1996). The legal and ethical components of executive decision-making: a course for business managers. J. Bus. Ethics 15, 571-579. doi: 10.1007/BF00381932

Page, C., Wilson, M., and Kolb, D. (1994). Managerial Competencies: On the Inside, Looking in?. Wellington: Ministry of Commerce.

Panagiotis, G. (2012). Innovation embedded in entrepreneurs' networks and national educational systems. Small Bus. Econ. 39, 495-515. doi: 10.1007/ sl1187-014-9546-8

Petra, R. K. (2016). Integrating factor analysis and the Delphi method in scenario development: a case study of Dalmatia. Croatia. J. Appl. Geogr. 71, 56-68. doi: 10.1016/j.apgeog.2016.04.007

Podsakoff, P. M., MacKenzie, S. B., Lee, J. Y., and Podsakoff, N. P. (2003). Common method biases in behavioral research: a critical review of the literature and recommended remedies. J. Appl. Psychol. 88, 879-903. 
Qu, Z. H. (2015). Research on the development of legal education in the teaching of "entrepreneurship foundation" course in universities. J. Innov. Entrepreneurship Educ. 6, 128-130.

Rauch, A. J., and Hulsink, W. (2015). Putting entrepreneurship education where the intention to act lies. An investigation into the impact of entrepreneurship education on entrepreneurial behaviour. Acad. Manage. Learn. Educ. 14, 187-204. doi: 10.5465/amle.2012.0293

Sascha, G. W., and Jörn, H. B. (2016). Outcomes of entrepreneurship education: An institutional perspective. J. Bus. Venturing 31, 216-233. doi: 10.1016/j.jbusvent. 2015.10.003

Shepherd, D. A. (2011). Multilevel entrepreneurship research: opportunities for studying entrepreneurial decision making. J. Manage. 37, 412-420. doi: 10.1177/ 0149206310369940

Spencer, L. M., and Spencer, S. G. (1993). Competence at Work: Models for Superior Performance. New York, NY: Wiley.

Stefan, A., Kerstin, C., Lars, G., Maria, H., Jana, H., and Monika, M. (2017). Real-time delphi in practice-a comparative analysis of existing softwarebased tools. J. Technol. Forecast. Soc. 118, 15-27. doi: 10.1016/j.techfore.2017. 01.023

Stewart, R. C., and Anne, R.-S. (2003). Revising the boundaries: management education and learning in a postpositivist world. Acad. Manage. Learn. Educ. 2, 85-98.

Su, X. Y., and Ma, Y. Q. (2011). Research on the cultivation to the compound talents in high school. Modern Edu. Forum. 11, 73-74. doi: 10.13694/j.cnki.ddjylt.2011. 10.037

Sun, X. Z. (2012). To Open up a New Era of Legal-Business Management: Reflections and Explorations on Legal-Business Management Issues in LegalBusiness Management Review. China: Economy \&Management Publishing House, 3-18.

Sun, X. Z. (2018). The wisdom of Law-Business Management Leading the Internationalization of Chinese Enterprises in Legal-Business Management Interpretation. China: Economy \&Management Publishing House, 159-165.

Sun, X. Z., Wang, L., and Wang, T. (2012). Explorations and Practices of Cultivating Legal-Business Interdisciplinary Talents in Legal-Business Management Review. China: Economy \&Management Publishing House, 183-193.

Virginia, B. S., and Carlos, A. S. (2018). Entrepreneurial intention among engineering students: the role of Entrepreneurship education. Eur. Res. Manage. Bus. Econ. 24, 53-61. doi: 10.1016/j.iedeen.2017.04.001
Walter, S. G., and Dohse, D. (2012). Why mode and regional context matter for entrepreneurship education. Entrepreneurship Reg. Dev. 24, 807-835. doi: 10.1080/08985626.2012.721009

Wang, B. Q., and An, J. (2015). On the ways of cultivating compound talents in science and engineering colleges. Educ. Vocat. 7, 2-3. doi: 10.13615/j.cnki.10043985.2015.07.044

Wang, L. (2012). Legal-business management model and its TDCA optimization tool in Legal-Business Management Review. China: Economy \& Management Publishing House, 27-39.

Wang, N. (2018). The setting of education law course on innovation and entrepreneurship in universities-a case study. J. Innov. Enterprise Educ. 9, 3-6.

Wang, T. (2017). American JD/MBA Law-business compound talents' training model and its enlightenment. High. Educ. Explor. 2, 94-97.

Wim, N., José, E. A., and Oscar, C. (2014). Surfeiting,the appetite may sicken: entrepreneurship and happiness. J. Small Busi. Econ. 42, 523-540. doi: 10.1007/ s11187-013-9492-x

Wu, Y. X. (2012). Perspective on the Concept and Connotation About Legal-Business Management From the View of Management in Legal-Business Management Review. China: Economy \& Management Publishing House, 52-73.

Xie, R. H. (2017). A study on the legal safeguard mechanism of college students' entrepreneurship from the perspective of risk theory. J. Univ. Educ. Manage. 11, 53-59. doi: 10.13316/j.cnki.jhem.20171027.007

Yue, C. Q. (2013). Analysis on the influencing factors of Chinese college graduates' employment satisfaction. J. Educ. Comment. Peking Univ. 11, 2-12. doi: 10. 19355/j.cnki.1671-9468.2013.02.007

Zhao, Y. X. (2015). The theoretical context and practical problems of the "lawbusiness vocational education". J. Hubei Univ. Econ. 12, 138-139.

Conflict of Interest Statement: The author declares that the research was conducted in the absence of any commercial or financial relationships that could be construed as a potential conflict of interest.

Copyright (c) 2019 Wang. This is an open-access article distributed under the terms of the Creative Commons Attribution License (CC BY). The use, distribution or reproduction in other forums is permitted, provided the original author(s) and the copyright owner(s) are credited and that the original publication in this journal is cited, in accordance with accepted academic practice. No use, distribution or reproduction is permitted which does not comply with these terms. 